\title{
Methods for Breaking Dormancy of Seeds of Tropical Forage Legumes
}

\author{
Leonardo F. de Morais', João C. C. Almeida1, Bruno B. Deminicis², Fábio T. de Pádua ${ }^{3}$, \\ Mirton J. F. Morenz" ${ }^{4}$ João B. R. de Abreu1, Raphael P. Araujo5, Delci D. de Nepomuceno ${ }^{1}$ \\ ${ }^{1}$ Department of Animal Science and Production, Federal Rural University of Rio de Janeiro, \\ Rio de Janeiro, Brazil \\ ${ }^{2}$ Department of Animal Science and Production, Federal University of Espírito Santo, \\ Vitória, Brazil \\ ${ }^{3}$ Federal Institute of Rio de Janeiro-IFRJ, Campus Nilo Peçanha-Pinheiral-RJ, Pinheiral, Brazil \\ ${ }^{4}$ Brazilian Agricultural Research Corporation, National Research Center of Dairy Cattle, Juiz de Fora, Brazil \\ ${ }^{5}$ Department of Animal Science, Federal University of São João Del Rei, São João Del Rei, Brazil \\ Email: joaocarlosbq@gmail.com, brunodeminicis@gmail.com, fabio.padua@ifri.edu.br, \\ morenz@yahoo.com.br, raphaelpavesi@yahoo.com.br
}

Received 15 March 2014; revised 14 April 2014; accepted 10 May 2014

Copyright (C) 2014 by authors and Scientific Research Publishing Inc.

This work is licensed under the Creative Commons Attribution International License (CC BY).

http://creativecommons.org/licenses/by/4.0/

c) (†) Open Access

\section{Abstract}

The aim of this study was to evaluate methods for breaking dormancy of seeds Neonotonia wightii (perennial soybean), Macrotiloma axilare (archer), Pueraria phaseoloides (tropical kudzu), Calopogonium mucunoides (calopo), which were subjected to the following treatments for physical breaks and physiological dormancy: 1) control; 2) scarification with sandpaper; 3) immersion in $\mathrm{H}_{2} \mathrm{SO}_{4} 98 \%$ for five minutes and subsequent washing in water; 4) preheating at $60^{\circ} \mathrm{C}$ for 150 minutes in an air circulating oven; 5) $0.2 \% \mathrm{KNO}_{3}$; and 6) gibberellic acid $\left(\mathrm{GA}_{3} \mathrm{0.5 \%}\right)$. The results showed that using $\mathrm{H}_{2} \mathrm{SO}_{4}$ to break seed dormancy archer and perennial soybean and calopo scarification with sandpaper were the most recommended treatments. Tropical Kudzu presented physiological response to treatments with the use of gibberellic acid and physical treatment using immersion $\mathrm{H}_{2} \mathrm{SO}_{4}$. Thus, it is necessary to use techniques to make the breaking dormancy of seeds of legumes, resulting in an increase in the rate of seed germination and rapid deployment of the legume.

\section{Keywords}

Fabaceae, Seed, Dormancy and Germination 


\section{Introduction}

The use of pastures is of utmost importance for cost reduction factors in animal husbandry, and its persistence can be achieved through new techniques, either recovery by training with the introduction of potentially more productive and/or the associated forage legumes [1]. The use of forage legumes in pastures has become a technique of growing use by farmers because it is a sustainable way to recover degraded pastures, and at the same time provide quality forage for animals. However, a major problem encountered is that the establishment phase of the legume, especially among all factors stands out seed quality [2].

The seed dormancy of legumes is an inherited trait, assigned to the palisade cell layer whose cell walls are thick and covered externally by a waxy cuticle. Under natural conditions, this impermeability gradually decreases, so that a certain percentage of seeds germinated in each period. However, in the laboratory, the rupture of the seed coat allows immediate imbibition and early germination process [3]. Thus, the immersion in hot water for a few minutes, scarification with sandpaper and chemical scarification with sulfuric acid have been used, successfully, to eliminate numbness in the integument of the leguminous seeds [4]. Knowledge of the quality of a seed depends a lot on the availability of accurate methodologies, which lead to reliable results [5]. Even with the use of reliable analysis for seed quality techniques, and under favorable conditions, some seeds do not germinate with the coat impermeability to water, and these are called hard seeds or cutaneous numbness, which according to [6] is an inherited trait, given the palisade layer of cells whose cell walls are thick and covered externally by a waxy cuticle.

When the technological level of the properties and use of seeds for pastures deployment increases, seed quality becomes increasingly important. So proper selection is very important for the production of fodder in adequate quality and quantity factor to meet the production needs of the business requires. It is common in legumes, the production of so-called hard seeds, i.e., dormant seeds according to their water impermeable seed coats, where soaking the seed is the first step in the process of germination [7].

For good germination, the seeds of leguminous plants need to undergo a process of scraping, which must be done preferably immediately prior to planting [8]. Thus, the study of methods to break seed dormancy of legumes is necessary, which increases the rate of seed germination and thus makes the process more efficient deployment of legumes in the pasture.

\section{Methods}

This study was conducted at the Institute of Animal Science, Federal Rural University of Rio de Janeiro (UFRRJ) in Brazil, between October and December 2012. The species used were: Neonotonia wightii (perennial soybean), Macrotiloma axilare (archer), Pueraria phaseoloides (tropical kudzu) and Calopogonium mucunoides (calopo), where its seeds were subjected to the following treatments for breaking dormancy [9]: 1) control; 2) scarification with sandpaper; 3 ) immersion in $\mathrm{H}_{2} \mathrm{SO}_{4} 98 \%$ for five minutes and subsequent washing in water; 4) preheating at $60^{\circ} \mathrm{C}$ for 150 minutes in an air circulating oven; 5) $0.2 \% \mathrm{KNO}_{3}$; and 6) gibberellic acid $\left(\mathrm{GA}_{3}\right.$ $0.5 \%$ ). The solutions of $\mathrm{KNO}_{3}$ and gibberellins were added to the substrate. Samples of the seeds used in the germination test were randomly taken from the portion of "pure seed" the analysis of purity. This portion, after homogenization of 200 seeds per treatment divided into 4 replicates of 50 seeds in germination BOD lightless chamber where the seeds were placed in boxes gerbox on paper germitest autoclaved $\left(120^{\circ} \mathrm{C} /\right.$ were counted 20 minutes), and soaked in distilled water at a ratio of 2.5 times the weight of the paper. The temperature used was $25^{\circ} \mathrm{C}$ for all species. The first evaluation of germination occurred on the 4th day after the assembly of the second test on the 10th day, and quantified the percentage of seed germination, which corresponded to the ratio of the number of seeds that produced seedlings classified as normal [9]. The experimental design was completely randomized, with the germination average subjected to analysis of variance, using the Tukey test at $5 \%$ significance. All values were transformed for analysis of variance in arcosen $\sqrt{(x / 100)}$.

\section{Results and Discussion}

The results of the germination tests for different methods of breaking dormancy are shown in Table 1. It was observed that for archer and perennial soybeans, using $\mathrm{H}_{2} \mathrm{SO}_{4}$ immersion was the method that had the highest percentage of germination, so the best method to effect the removal of dormancy. According to [10], the perennial soybean germination without scarification has a ranging between $7 \%$ and $24 \%$, with immersion in $\mathrm{H}_{2} \mathrm{SO}_{4}$ 
Table 1. Results of germination tests for the different treatments: control, scarification with sandpaper, soaking in $98 \%$ $\mathrm{H}_{2} \mathrm{SO}_{4}, \mathrm{H}_{2} \mathrm{O}$ immersion in $80^{\circ} \mathrm{C}$ pre-heating at $60^{\circ} \mathrm{C}$ for 150 minutes at $0.2 \% \mathrm{KNO}_{3}$ and $0.5 \%$ gibberellic acid $\left(\mathrm{GA}_{3}\right)$.

\begin{tabular}{|c|c|c|c|c|}
\hline \multirow[b]{2}{*}{ Treatments } & \multicolumn{4}{|c|}{ Percentage of seed germination $(\%)$} \\
\hline & Archer & Perennial soybean & Calopo & Tropical kudzu \\
\hline Heating & $18.8^{\mathrm{BC}}$ & $33.5^{\mathrm{BC}}$ & $48.4^{\mathrm{AB}}$ & $39.0^{\mathrm{A}}$ \\
\hline $\mathrm{KNO}_{3}$ & $22.5^{\mathrm{BC}}$ & $21.5^{\mathrm{C}}$ & $35.5^{\mathrm{C}}$ & $21.0^{\mathrm{B}}$ \\
\hline Control & $24.5^{\mathrm{BC}}$ & $26.0^{\mathrm{BC}}$ & $40.0^{\mathrm{BC}}$ & $18.0^{\mathrm{B}}$ \\
\hline $\mathrm{GA}_{3}$ & $24.5^{\mathrm{BC}}$ & $23.0^{\mathrm{BC}}$ & $41.5^{\mathrm{BC}}$ & $47.5^{\mathrm{A}}$ \\
\hline Sandpaper & $32.0^{\mathrm{AB}}$ & $31.0^{\mathrm{BC}}$ & $54.0^{\mathrm{A}}$ & $42.0^{\mathrm{A}}$ \\
\hline $\mathrm{H}_{2} \mathrm{SO}_{4}$ & $47.5^{\mathrm{A}}$ & $52.0^{\mathrm{A}}$ & $51.0^{\mathrm{AB}}$ & $47.0^{\mathrm{A}}$ \\
\hline $\mathrm{CV} \%$ & 12.61 & 17,27 & 11.69 & 14.31 \\
\hline
\end{tabular}

*Means followed by the same capital letter in the column don't differ statistically among themselves by Tukey test at $5 \%$ probability.

there was a $100 \%$ increase in the germination of their seeds compared to the control which showed only $26 \%$ germination.

[11] studied treatments to overcome dormancy of Sterculia striata concluded that scarification with sandpaper number 80 on the opposite side of micropylar favors the percentage of seedlings in the first count, and recommended rapid and uniform emergence of seeds of Sterculia striata, but the mechanical scarification no increases germination of the studied species, however, in other species the scarification with sandpaper favors the germination of seeds that have water-impermeable seed coat, as well as seeds of Senna macranthera [12], Ocotea corymbosa [13], Leucaena diversifolia [14], Operculina macrocarpa [15], Acacia mearnsii [16], Ormosia arborea [17], Schizolobium amazonicum [18], Leucaena leucocephala [7] and Senna siamea [19].

Among the legumes studied, only tropical kudzu showed physiological response to treatments for breaking dormancy with Gibberellin, which did not differ statistically from immersion in $\mathrm{H}_{2} \mathrm{SO}_{4}$. According [20] the presence of more than one cause of dormancy, was found in the seeds of various species, as in the forage legume Stylosanthes humilis, which has an "exogenous" (Physics) and other "endogenous" (physiological) dormancy. To calopo using scarification with sandpaper had the highest percentage of germination [21], suggests that this treatment is used to overcome seed dormancy butterfly pea, perennial soybean and archer, because it showed better results for germination percentage among the treatments studied, and can be a recommended technique for producing low financial resource, by requiring low cost and easy driving by the producer.

These results reaffirm that the seeds of the studied species have cutaneous numbness. This dormancy is a function of the tissues surrounding the seeds exerting an obstacle, causing impermeability of the seed coat or pericarp to water and oxygen, the presence of the chemical inhibitors in the pericarp or seed coat, such as coumarin or sorbic acid, or tissues simply act as physical development of the embryo [22] barrier. Thus, it can be seen that all the treatments studied responded to overcome the principle of rupture of the integument thus provided imbibition and hence the germination of seeds. When the seeds were subjected to different methods of scarification, it was found that the treatment with sulfuric acid blunts, sandpaper and hot water had higher percentages of emergency, with values between $49.37 \%, 39.75 \%$ and $37.92 \%$. In studies of Caesalpinia ferrea [23], found higher in treatments underwent emergency emerges, when compared to those submitted to immersion in hot water and seeds that have not undergone pre-germination treatments.

[24] found that treatment with immersion in water at $100^{\circ} \mathrm{C}$ and sulfuric acid for periods of 10 and 15 min showed higher germination percentage in seeds Piptadenia moniliformis; otherwise, [25] in studies with the same species, found higher percentages of germination in treatments subjected to immersion in sulfuric acid for 20, 25 and $30 \mathrm{~min}$. [26] found an increase in the percentage of germination of seeds immersed in sulfuric acid for up to $15 \mathrm{~min}$, from that time, the germination percentage begins to decrease, the fact that, according to the authors, denotes the onset of damage seed due to an excessively long period of exposure to sulfuric acid. [27] studied seed dormancy in Piptadenia stipulacea found that seeds presented integumentary dormancy and the following pregerminative emerge treatments were used to overcome it:, immersion in water at $100^{\circ} \mathrm{C}(1,2$ or 3 $\mathrm{min})$ or in sulfuric acid (95\%) for $10 \mathrm{~min}$. 
In this study treatment with sulfuric acid was evidenced as an efficient method to break dormancy of seeds of the studied species, however, [11] measured the treatments with sulfuric acid were not effective in breaking dormancy of Sterculia striata, were not statistically different from the control. However, in other work performed treatments with sulfuric acid induced increases and uniformity in germination of Senna macranthera [28], Parkia multijuga [29], Cassia excelsa [30], Bauhinia monandra [31], Mimosa caesalpiniifolia [26], Ormosia arborea [17], Ochroma lagopus [32], Zizyphus joazeiro [23] and Ormosia nitida [33].

\section{Conclusion}

The use of immersion in $\mathrm{H}_{2} \mathrm{SO}_{4}$ for five minutes to archer and perennial soybeans, scarification with sandpaper to calopo was the most suitable way to break the dormancy of its seeds. Tropical Kudzu presented physiological response to treatments with the use of gibberellic acid and physical treatment using $\mathrm{H}_{2} \mathrm{SO}_{4}$ immersion for five minutes.

\section{References}

[1] Souza, S.O., Santana, J. and Shimoda, A. (2002) Behavior of Isolated Tropical Forage Grasses and Legumes in Association with the North Fluminense. Science and Agrotechnology, 26, 1554-1561.

[2] Kyneur, G.W. (1962) The Role of Fertiliseres in Establishing Glycine javanica. L. on Latosol Soil. Proceedings. N. Queensl. Agros. Conf., 10-15.

[3] Fernandez, C.D., Grof, B. and Carvalho, J. (2000) Mechanical Scarification of Seeds of Stylosanthes spp. with Rice Processing Equipment. Embrapa, 4 p.

[4] Perez, S.C.J.G.A. (2004) Wraps. In: Ferreira, A.G. and Borghetti, F., Eds., Germination: From Basic to Applied, Artmed, Porto Alegre, 125-134.

[5] McDonald, M.B. (1998) Seed Quality Assessment. Seed Science Research, Wallingford, 8, 265-275.

[6] Sune, A.D. and Franke, L.B. (2006) Dormancy Breaking and Germination Testing Methodologies in Trifolium riograndense Burkart and Desmanthus depressus Humb. Brazilian Journal of Seeds, 28, 29-36.

[7] Deminicis, B.B., Almeida, J.C.C., Blume, M.C., Araújo, S.A.C., Pádua, F.T., Zanine, A.M. and Jaccoud, C.F. (2006) Overcoming Dormancy in Seeds of Eight Tropical Forage Legumes. Archivos de Zootecnia, 55, 401-404.

[8] Adams, R.M., Koenigsberg, S.S. and Langhans, R.W. (1979) In Vitro Propagation of Cephallotus folicularis (Australian Patcher Plant). Horticultural Science, 14, 512-513.

[9] Brasil (2009) Ministério da Agricultura, Pecuária e Abastecimento. Rules for Testing Seeds. Brasilia: SNDA/DNDV/CLAV, 395 p.

[10] Neme, A.N. (1963) Perennial Soybean Seeds. Results of Scarification and Duration of Power Twinning. Bragantia: Scientific Bulletin of the Agricultural Institute of the Sao Paulo State, 22, 785-791.

[11] Silva, K.B., Mata, M.F. and Bruno, R.L.A. (2012) Pregerminative Treatments to Overcome Dormancy of Sterculia striata A. St. Hil. \& Naldin Seeds. Semina: Ciências Agrárias, 33, 857-866. http://dx.doi.org/10.5433/1679-0359.2012v33n3p857

[12] Santarém, E.R. and Aquila, M.E.A. (1995) Influence of Methods of Scarification and Storage on Seed Germination of Senna macranthera (Colladon) Irwin \& Barneby (Leguminosae). Brazilian Journal of Seeds, 17, 205-209.

[13] Bilia, D.A.C., Barbedo, C.J. and Maluf, A.M. (1998) Germination of Diaspores of Ocotea corymbosa (Meissn.) Mez-(Lauraceae) as a Function of Temperature, Substrate and Numbness. Brazilian Journal of Seeds, 20, 189-194.

[14] Bertalot, M.J.A. and Nakagawa, J. (1998) Overcoming Dormancy in Seeds of Leucaena diversifolia (Schlecht.) Bentham K156. Brazilian Journal of Seeds, 20, 39-42.

[15] Medeiros Filho, S., França, E.A. and Innecco, R. (2002) Germination Seeds of Operculina macrocarpa (L.) Farwel e Operculina alata (Ham.) Urban. Brazilian Journal of Seeds, 24, 102-107.

[16] Roversi, T., Mattei, V.L., Silveira Júnior, P. and Falck, G.L. (2002) Overcoming Dormancy in Seeds of Acacia mearnsii Willd. Brazilian Journal of Agroscience, 8, 161-163.

[17] Lopes, J.C., Dias, P.C. and Macedo, C.M.P. (2006) Treatments to Accelerate Germination and Reduce the Deterioration of Seeds Ormosia nitida Vog. Tree Magazine, 30, 171-177.

[18] Cruz, E.D. and Carvalho, J.E.U. (2006) Methods of Overcoming Dormancy in Schizolobium amazonicum Huber ex Ducke (Leguminosae - Caesalpinioideae) Seeds. Brazilian Journal of Seeds, 28, 108-115.

[19] Dutra, A.S., Medeiros Filho, S., Teófilo, E.M. and Diniz, F.O. (2007) Seeds Germination of Senna siamea (Lam.) H.S. Irwin e Barneby-Caesalpinoideae. Brazilian Journal of Seeds, 29, 160-164. 
[20] Burin, M.E. (1979) Chemical Regulation of Endogenous Dormancy of Stylosanthes humilis H.B.K. Master's Dissertation, UFV, Viçosa, 51 p.

[21] Deminicis, B.B. (2009) Potential Physiological Seed for Deployment by Cattle Pastures. Uenf, Thesis (Doctor of Plant Production), Darcy Ribeiro State University of Northern of Rio de Janeiro, Campos dos Goytacazes, 143 p.

[22] Fowler, J.A.P. and Bianchetti, A. (2000) Dormancy in Tree Seeds. Embrapa Florestais, Colombo (Document, n. 40).

[23] Coelho, M.F.B., Maia, S.S.S., Oliveira, A.K. and Diógenes, F.E.P. (2010) Overcoming Seed Dormancy in Cutaneous Caesalpinia ferrea Mart ex Tul. Brazilian Journal of Agricultural Sciences, 5, 74-79.

[24] Benedito, C.P., Torres, S.B., Ribeiro, M.C.C. and Nunes, T.A. (2008) Overcoming Seed Dormancy in Piptadenia moniliformis Benth. Agronomic Science Magazine, 39, 90-93.

[25] Azeredo, G.A., Paula, R.C., Valeri, S.V. and Moro, F.V. (2010) Overcoming Seed Dormancy in Piptadenia moniliformis Benth. Brazilian Journal of Seeds, 32, 49-58.

[26] Garcia, J., Duarte, J.B. and Frasseto, E.G. (2002) Overcoming Seed Dormancy in Mimosa caesalpiniaefolia L. Tropical Agricultural Research, 32, 29-31.

[27] Farias, R.M., Freitas, R.M.O., Nogueira, N.W. and Dombroski, J.L.D. (2013) Overcoming of Dormancy of Piptadenia stipulacea Seeds. Amazonian Journal of Agricultural and Environment Sciences, 56, 160-165.

[28] Eschiapati-Ferreira, M.S. and Perez, S.C.J.G.A. (1997) Treatments to Overcome Dormancy Seeds of Senna macranthera (Collad.) Irwin et Barn. (Fabaceae-Caesalpinoideae). Brazilian Journal of Seeds, 19, 230-236.

[29] Bianchetti, A., Teixeira, C.A.D. and Martins, E.P. (1998) Acid Scarification to Overcome Dormancy Seeds of Parkia multijuga Benth. Brazilian Journal of Seeds, 20, 215-218.

[30] Jeller, H. and Perez, S.C.J.G.A. (1999) Estudo da superação da dormência e da temperatura em sementes de Cassia excelsa Schrad. Brazilian Journal of Seeds, 21, 32-40.

[31] Alves, M.C.S., Medeiros Filho, S., Andrade Neto, M. and Teófilo, E.M. (2000) Overcoming Seed Dormancy in Bauhinia monandra britt. and Bauhinia ungulata L.-Cesalpinoideae. Brazilian Journal of Seeds, 22, 139-144.

[32] Barbosa, A.P., Sampaio, P.T.B., Campos, M.A.A., Varela, V.P., Gonçalves, C.Q.B. and Iida, S. (2004) Alternative Technology for Breaking Seed Dormancy of Ochroma lagopus Sw, Bombacaceae. Acta Amazônica, 34, 107-110. http://dx.doi.org/10.1590/S0044-59672004000100013

[33] Alves, E.U., Bruno, R.L.A., Oliveira, A.P., Alves, A.U. and Alves, A.U. (2006) Sulfuric Acid in Breaking Dormancy of Dispersal Units of Zizyphus joazeiro Mart. Tree Magazine, 30, 187-195. 